\title{
The Different Faces of History in Post-industrial landscapes
}

\section{Jozef Keulartz}

In order to elucidate the workshop's main topic about the place of history in the management of former military sites I will discuss the management of industrial heritage sites in NorthWest Europe. Examples from England, Germany and the Netherlands show that different national styles in regenerating and revitalizing post-industrial landscapes reflect different deep-seated attitudes towards their own history. To describe these attitudes I will make use of Friedrich Nietzsche's work "On the Use and Abuse of History for Life". Nietzsche questions the belief that historical knowledge is intrinsically valuable. He argues that history is valuably only insofar as it serves life, and he identifies different forms of history, each with a unique ability to help or hinder life. I will first provide a brief overview over these forms of history and then try to apply them to the different post-industrial landscapes.

\section{Nietzsche's trinity}

Nietzsche distinguishes three forms of history: antiquarian, critical and monumental history. Each of these forms can be put in the service of life, but each may also degenerate into a threat to life. This happens when one form of history gains supremacy at the expense of the other two. Nietzsche's ideal is that of a balance, where the different forms of history may complement and correct each other.

\section{Antiquarian history}

Antiquarian history appeals to a person's or a people's inclination for preservation and admiration of the past. The antiquarian looks back at the origins of his existence with love and loyalty. He wants to preserve the conditions under which he came into existence for those who are to come after him. Nurturing what has stood from time immemorial provides antiquarians with a sense of continuity and collective identity. This antiquarian sense offers man the assurance that his existence is neither arbitrary nor accidental, but rather a link in a chain of events extending from the past, and therefore, justified.

The antiquarian has an instinct for nuances and details. This devotion to specifics may lead to a narrowed vision in which things are looked at too closely and in isolation. Especially when antiquarian history rules over the other forms of history, the antiquarian tends to perceive everything old and past as equally worthy of respect and to make no distinction between what is truly important and what is less important.

There is, moreover, always the danger that everything old will be overestimated, whereas everything new is rejected and treated with hostility. When this happens, when things of the past are valued more than things of the present, antiquarian history no longer serves life, but mummifies it. We then see "the wretched drama of a blind mania for collecting, a restless compiling together of everything that ever existed". As it threatens to paralyze the present with its reluctance to replace the old with the new, antiquarian history leads to an ongoing musealization of the past. It then only knows how to preserve life, not how to create it, as it always undervalues what is emergent.

\section{Monumental history}

Monumental history opposes the mummification of life and the musealization of the past and offers a counterbalance to a degenerated antiquarian history that no longer gives inspiration to the fresh life of the present. Monumental history can serve life by inspiring contemporary man to creatively and courageously shape his present and future. It examines the past with the 
explicit intent of finding teachers and role models to be emulated and surpassed, encouraging and empowering man to attain excellence and greatness. Monumental history is concerned with the greatest moments in the history of humanity that serve to indicate that greatness has once been attained and will therefore be possible once again. This knowledge offers strength and power, and takes away the self-doubt, which frustrates creativity, that she might perhaps be wishing for the impossible.

Whereas antiquarian history tends to get bogged in little details and fine distinctions, monumental history has a tendency to overlook or tone down differences in motives and occasions. To draw strength from historical examples, the uniqueness and individuality of the past will usually be forced into a general formula. As long as the past is mainly used as model worthy of imitation, it is in constant danger of becoming deformed and distorted. If monumental history dominates the other forms of history - the antiquarian and the critical then large parts of the past are forgotten and despised, and the distinction between monumental history and mythical fiction will frequently be blurred.

When the past is not intrinsically valued, but only because of its monumental effects, there is always the danger that history will degenerate into a miscellaneous collection, a grab bag, from which forms, concepts, structures et cetera can be drawn opportunistically without any quality criteria.

\section{Critical history}

Critical history serves as remedy against the pathologies of antiquarian and monumental history. In order to overcome the paralyzing obsession with the past, without relapsing into a superficial pursuit of monumental effects, man must have the strength to shatter and dissolve a past and to erase memories. This he achieves, says Nietzsche, "by dragging history to the bar of judgment, interrogating it meticulously and finally condemning it". Through this critical analysis of history, it is possible for man to discover knowledge that conflicts with his nature; critical history then gives him the power to utilize this new knowledge to his advantage and "implant a new habit, a new instinct, a second nature so that the first nature withers away".

Cutting ties to the past thus gives a sense of liberation and emancipation. It allows us to move forward towards growth and progress and raises hope for a future without suffering and injustice. But although condemnation of the past is useful for the present, it can also degenerate into a dangerous practice for life itself. Just because we destroy the past does not mean we can escape the past; for we derive from the past. We are merely the products of previous generations with all their aberrations, passions, errors, and crimes, and we are unable to shake off this chain entirely. If we deny this fact, our hope for a fair and decent future may turn out to be a false hope.

\section{Post-industrial histories}

I will now try to apply Nietzsche's trinity of the antiquarian, the monumental and the critical history to the different forms of design and management of post-industrial sites.

\section{The Geevor Tin Mine Heritage Centre}

In England, a country that is proud of its history and that cherishes nostalgic sentiments, the emphasis is clearly on preservation and restoration of the industrial past. The Geevor Tin Mine Heritage Centre at the coast of Cornwall is a good example of the preference to turn former industrial sites into open-air museums, that invite visitors to relive the past as concrete and authentic as possible. 


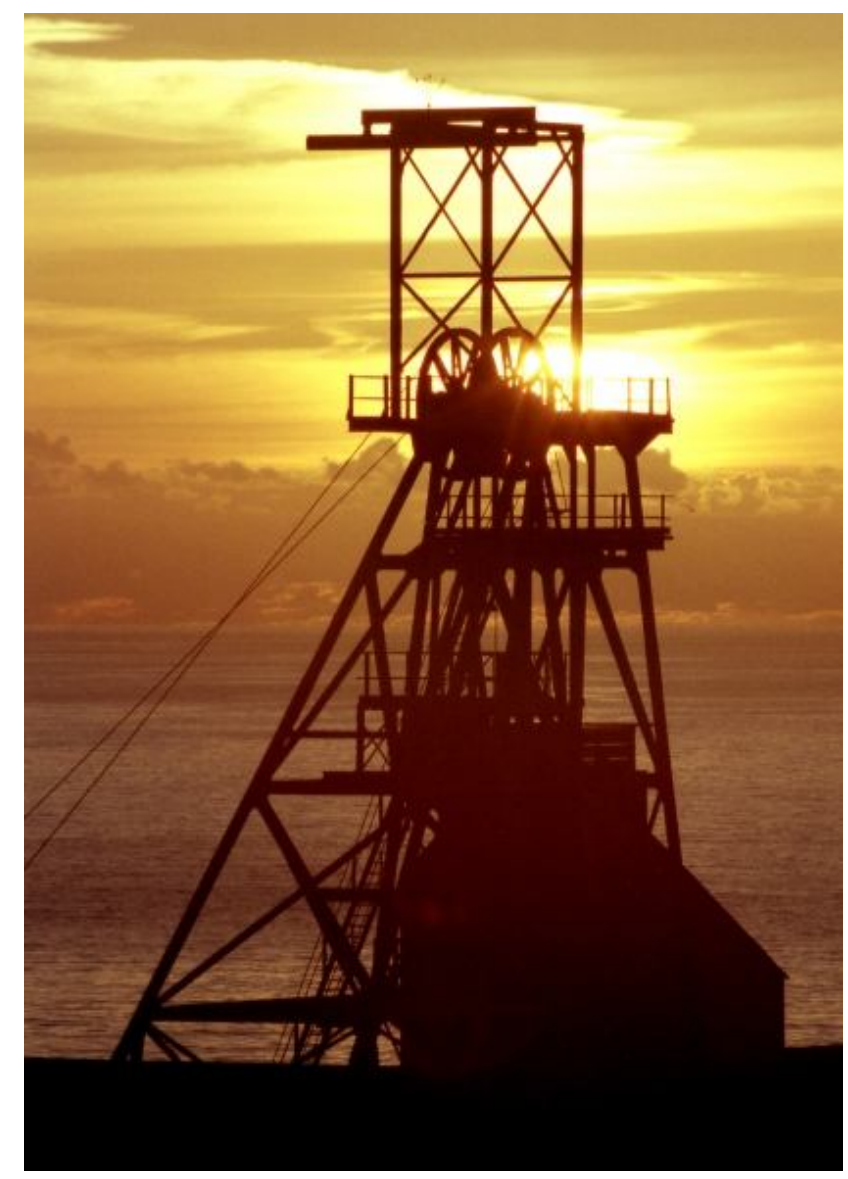

Tin mining has long been the main economic activity in Cornwall and has formed the landscape and its residents. The mining activities in the area date back to the 17th century. Geevor Tin Mine was one of the largest tin mines in the Cornwall area, employing up to 400 people, with workings extending far out under the sea. In 1990, this mine was closed, leading to much unemployment. On the initiative of former miners in collaboration with the local government, the area was transformed into a heritage centre. It is now the largest mining history site in the UK where visitors can follow the story of the mining and processing of tin. The site now functions as an open-air museum: the buildings and machinery have been returned to their original state as much as possible, while parts of the former mine shafts have been pumped dry again. Visitors can get guided tours by former miners, and thus experience life as an underground laborer. There is a unique collection of mining artefacts, mineral displays and photographs of the mine and miners at work.

With its strong emphasize on preservation and admiration of the past, Geevor Tin Mine Heritage Centre is clearly an example of antiquarian history. There is an imminent danger that the centre will not be able to inspire 'the fresh life of the present'. The mine has not really received a second life, but only has its first life prolonged after retirement. It is questionable whether this is sufficient to provide the region with new impulses.

\section{The Western Gas Factory}

The Dutch management style with respect to derelict industrial sites is less conservative than the English style. Because the Netherlands is a very densely populated country where space is scarce, the Dutch have developed a pragmatic style, giving new functions to old buildings and structures, as the example of the Western Gas Factory, a coal gas factory complex near the historic centre of Amsterdam, clearly shows. 


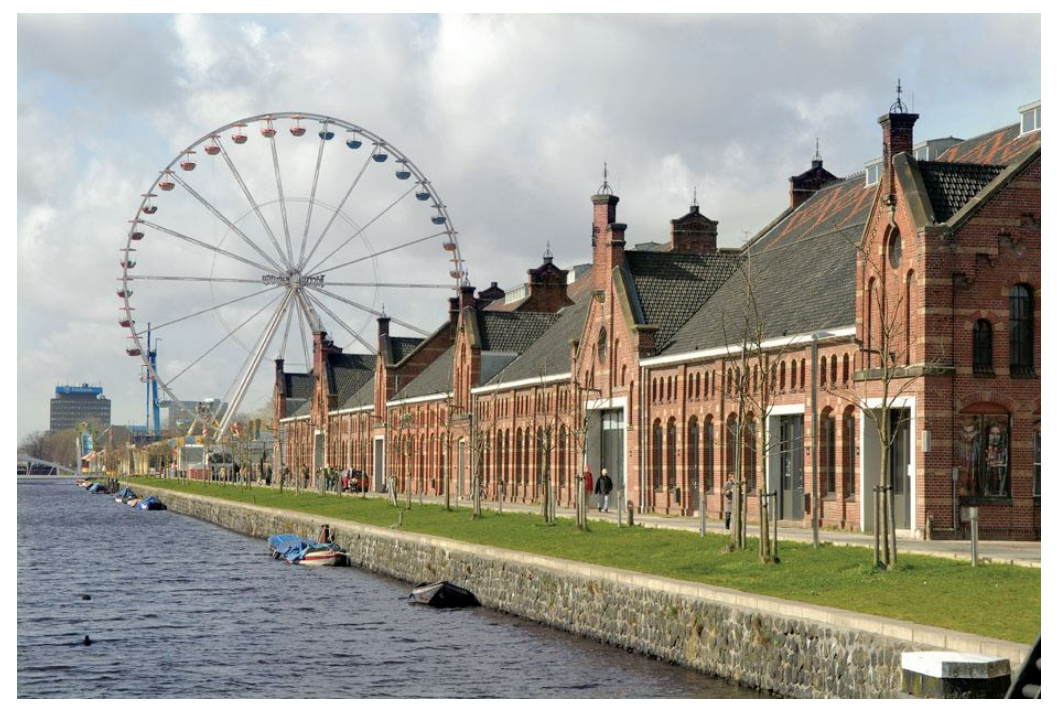

The Western Gas Factory was built in 1883 by the Imperial Continental Gas Association (ICGA) of London. The factory, located on the outskirts of Amsterdam, was the largest gas extraction plant in the Netherlands. The gas was extracted from coal and used for street lightning. Gas production at the Western Gas Factory ceased in 1967.

Many of the buildings on site were designed by architect Isaac Gosschalk in the Dutch Neo Renaissance style, that was introduced by himself and that was popular between 1870 and 1915, during a period of economic growth often likened to the Golden Age in the 17th century. After 1992, the buildings were renovated and are now used for an variety of creative activities and cultural events. Artists set up studios in the smaller buildings. The large spaces such as the Gasholder are regularly used for exhibitions, house parties, fashion shows and festivals. On the site there are also various small companies with a permanent lease, such as a traditional bakery, a coffeehouse, and a cinema.

The park surrounding the buildings was designed by landscape architect Kathryn Gustafson. Her design, called 'Changement', shows the gradual transition from city to countryside. The use of the park is intensive and varied: big concerts, information markets, neighbourhood parties, picnics, football, et cetera. The park also has attractive green cycle and walking routes.

The successful redevelopment of the Western Gas factory is a good example of monumental history. It reminds one of the motto 'conservation through development' from the Dutch Belvedere Memorandum (1999). The memorandum argues for a new balance or synthesis between the preservation of existing historic values and the creation or development of new spatial values and new forms of use. Not the intrinsic value of the past is important but its usefulness and relevance for the present and the future. The renovation of the Western Gas Factory was carried out with the intention to give the local community new social and economic impulses by attracting business enterprises and cultural ventures.

In contrast to the first case, the Western Gas Factory has certainly received a second life, but insofar as the past is only opportunistically used because of its monumental effects, this new life is always in danger of becoming shallow.

\section{Landscape Park Duisburg Nord.}

In Germany, a country with a critical attitude toward its history, the emphasis is not on conservation or restoration, but on new beginnings and possibilities for change. An excellent example of such a critical attitude is Landscape Park Duisburg Nord.

The park site is the location of the former steelworks plant, that was build in 1901 by the famous German industrialist August Thyssen, immediately adjacent to the coal fields he 
had acquired previously. Until its closure in 1985, when overcapacity in the European steel market had to be reduced, the plant produced millions of tons of pig iron. The decline of the coal and steel production left behind an industrial wasteland of more than 200 hectares, a bizarre landscape of rail beds, smokestacks, slag heaps, polluted soils, industrial ruins, and reengineered waterways.

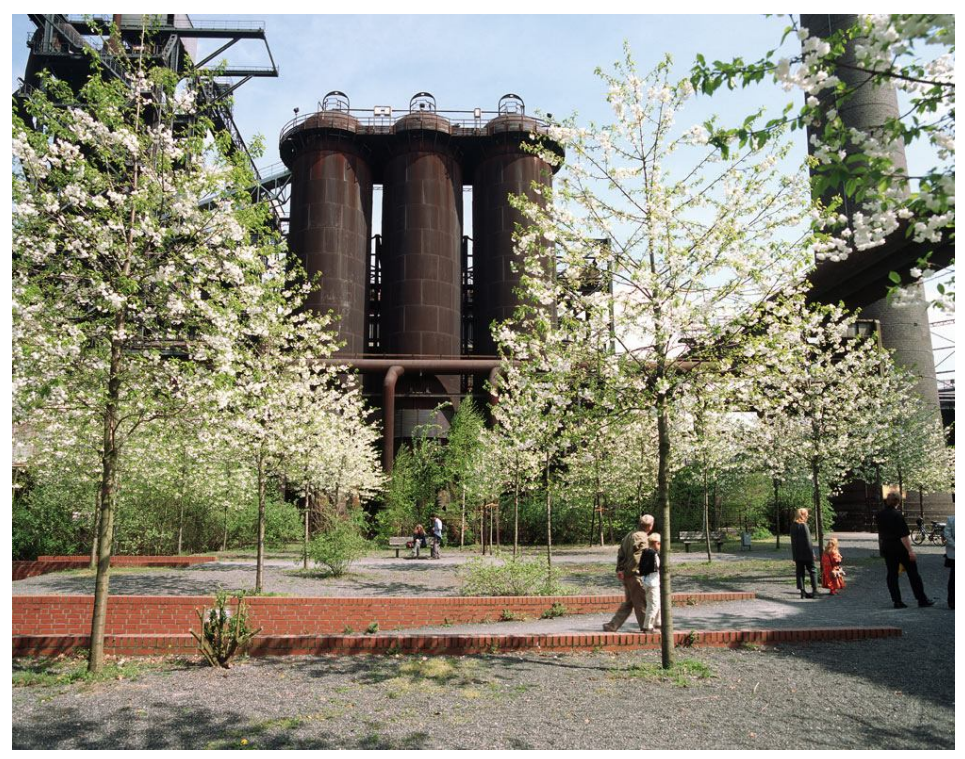

A citizens' action group successfully protested against the demolition of the old iron and steel works, and from 1989 to 1999 a new type of landscape park was created. It was not the intention of landscape architect Peter Latz, the leading designer of the park, to idealize the industrial past, and to turn the site into an open-air museum. The park was supposed to tell the story of hard labor, but also, and above all, the story of the decay of the site and the takeover of nature. Soon after the plant had been shut down, the buildings and structures became overgrown by vegetation, with lots of exotic plant and tree species which had travelled there with the iron ore. The reoccupation of the site by nature was not to be stopped but should be stimulated. To draw attention to this process, the Peter Latz deliberately opted for tight patterns in the additions he made, thereby stressing the contrast between spontaneous and designed nature.

Another spontaneous event was the discovery of the former ore storage bunkers as a climbers' paradise. Since 1990 the Duisburg section of the German Alpine Association has built its own 'climbing garden' in the landscape park. The varying degrees of steepness of the walls and the well preserved towers are ideally suited for climbing. There is also a via ferrata created in authentic Alpine style secured with a steel rope which mountain climbers use to prepare themselves for tours in the Alps.

In a similar vein, the Duisburg North Park Diving Club transformed the gasometer into the largest indoor diving basin centers in Europe. The club members filled the gasometer with 21 million liters of rainwater and created a new underwater landscape by sinking an artificial coral reef, a ship wreck and an old van.

Whereas the focus on nature reclaiming the landscape testifies to a critical attitude, the reuse of buildings and structures by climbers and divers also reveals something of a monumental attitude. This attitude is most evident in the conversion of the former halls of industry into locations for theatre, concerts, conferences and conventions. One can, moreover, even detect an antiquarian attitude, insofar as the park is not only about reusing but also about remembering and respecting important historical values.

Unlike the English and the Dutch example, Landscape Park Duisburg Nord presents a design in which Nietzsche's three forms of history can be identified. 